\title{
A NOVEL CORONAVIRUS TRANSMISSION FROM CHINA TO PAKISTAN VIA DIFFERENT COUNTRIES; A REVIEW.
}

\author{
1. M.Phil \\ Assistant Professor Rehabilitation \\ Islamabad Medical and Dental \\ College, Islamabad. \\ 2. FCPS (ENT) \\ Associate Professor \\ Islamabad Medical and Dental \\ College, Islamabad. \\ 3. MD Nephrology \\ Assistant Professor \\ Islamabad Medical and Dental \\ College, Islamabad. \\ Correspondence Address: \\ Dr. Naveed Arshad \\ Department of Rehabilitation \\ Islamabad Medical and Dental \\ College, Islamabad. \\ Main Murree Road Islamabad. \\ oliajann@gmail.com
}

Article received on:

26/02/2020

Accepted for publication:

28/03/2020

\begin{abstract}
Naveed Arshad', Syed Ali Naqi ${ }^{2}$, Jais Karmani ${ }^{3}$
ABSTRACT: A review of novel coronavirus transmission from China to globally is a serious illness or just a thread to world population. In the beginning cases of novel coronavirus (COVID-19), were found with infected pneumonia (NCIP) in Wuhan city, China, during December 2019 and January 2020. An outbreak of 2019 novel coronavirus diseases (COVID-19) in Wuhan, China has spread quickly national and international wide through transportation and travelling of people. Covid-19 outbreak was idiopathic, and it got attention not only nationally but internationally. Health authorities got activated and they took immediate actions for prevention, diagnosis, and treatment of the condition. They use precaution by isolating the people infected with it even who were suspected, did close monitoring of the patients and discovered different treatment procedures and diagnostic tests to combat the disease. Electronic articles search and data collected were done through PubMed, Google Scholar and Medline, using the following keywords: coronavirus, coronavirus transmission and outbreak, and coronavirus review. All types of articles were included to discuss Covid-19 transmission national as well as international included Pakistan.
\end{abstract}

Key words: $\quad$ Coronavirus Infection, Covid-19, China, Pakistan, Transmission.

Article Citation: Arshad N, Naqi S A, Karmani J. A novel coronavirus transmission from China to Pakistan via different countries; A review. Professional Med $\mathrm{J}$ 2020; 27(4):876-879. DOI: 10.29309/TPMJ/2020.27.04.4683

\section{INTRODUCTION}

By December 2019, Wuhan city of China became the center of pneumonia epidemic of unknown cause. By January 2020, the novel virus was isolated as by Chinese scientists named as covid-19. This rapid outbreak raised serious attention at national and international levels and within weeks, it was recognized as a pandemic by the World Health Organization, crossing Wuhan and rapidly disseminating in 171 countries/ regions worldwide. ${ }^{1}$ So far (March 18,2020 ), there are 7500 confirmed cases of COVID-19 and 117 deaths in the United States. ${ }^{2}$ In Iran, reported confirmed cases are 7161 and the death count reported to be 237 , since mid-February, 2020, while the real number is believed to be higher. On March 9, 2020, Kianush Jahanpour, a spokesperson from the health ministry, confirmed more than 40 more deaths due to Covid-19. Afghanistan, Pakistan, Bahrain, Kuwait, Iraq, Lebanon, Qatar, Oman, United Arab Emirates and Saudi Arabia has also reported cases linked to Iran. ${ }^{3}$ Kingdom of Saudi Arabia (KSA) confirmed 171 cases to date (March 18, 2020) and has imposed a lockdown temporarily in Shia-Muslim populated area Qatif to control the spread of coronavirus. ${ }^{4}$ Pakistan reported 272 cases on March 18, 2020, among them 21 cases were noted as imported from Syria. The global outbreak of coronavirus the World Health Organization has announced this is a pandemic. ${ }^{5}$ Pakistan is a country with more than $\mathbf{2 0 0}$ million populations and Pakistan's state health minister told that all confirmed cases of Covid-19 are related to epidemics in Syria, Iran, China, and Iraq. The majority of cases in Pakistan are reported in Sindh, followed by Punjab, Baluchistan and other provinces, while the number is rapidly raising every next day. ${ }^{5}$

\section{SEVERITY}

By January 23, 2020, the total number of laboratories confirmed cases of Covid-19 detected in China were 835 of whom 25 died. 
Even, all the cases detected outside the city of Wuhan had at least one family cluster. ${ }^{6}$ The disease has widespread human to the human risk of transmission. The first 41 cases infected with coronavirus were studied for its features. The non-specific clinical features of covid-19 include dry cough, fever, and malaise. Upper respiratory tract symptoms are infrequent. Laboratory findings include lymphopenia, bilateral groundglass opacity or chest consolidation on CT scans. Clinical presentation of Covid-19 confounds with influenza and other viral infections of the respiratory tract. Therefore, it becomes confusing and panic in case of any type of viral infection. ${ }^{7}$

\begin{tabular}{|c|c|c|c|}
\hline \multicolumn{4}{|c|}{ Demographics } \\
\hline Date & $\begin{array}{c}\text { December, } \\
2019\end{array}$ & $\begin{array}{l}\text { June, } \\
2012\end{array}$ & $\begin{array}{c}\text { November, } \\
2002\end{array}$ \\
\hline $\begin{array}{l}\text { Location of } \\
\text { first detection }\end{array}$ & $\begin{array}{l}\text { Wuhan, } \\
\text { China }\end{array}$ & $\begin{array}{c}\text { Jeddah, } \\
\text { Saudi } \\
\text { Arabia }\end{array}$ & $\begin{array}{c}\text { Guangdong, } \\
\text { China }\end{array}$ \\
\hline $\begin{array}{l}\text { Age, years } \\
\text { (range) }\end{array}$ & $20-75$ & $14-94$ & $1-91$ \\
\hline $\begin{array}{l}\text { Male: Female } \\
\text { Ratio }\end{array}$ & $2.7: 1$ & 3.3:1 & $1: 1.25$ \\
\hline $\begin{array}{l}\text { Confirmed } \\
\text { cases }\end{array}$ & $80,894^{\star}$ & 2494 & 8096 \\
\hline Mortality & $3,237^{*}(4 \%)$ & $858(37 \%)$ & $744(10 \%)$ \\
\hline \multicolumn{4}{|l|}{ Symptoms } \\
\hline Fever & $99 \%$ & $98 \%$ & $98-100 \%$ \\
\hline Dry cough & $84 \%$ & $47 \%$ & $30-75 \%$ \\
\hline Dyspnoea & $60 \%$ & $72 \%$ & $40-42 \%$ \\
\hline Diarrhoea & $10 \%$ & $26 \%$ & $20-25 \%$ \\
\hline Sore throat & $10 \%$ & $20 \%$ & $12-25 \%$ \\
\hline $\begin{array}{l}\text { Ventilator } \\
\text { Support }\end{array}$ & $10 \%$ & $80 \%$ & $14-20 \%$ \\
\hline \multicolumn{4}{|c|}{ Table-I. Covid-19 outbreak } \\
\hline
\end{tabular}

*:These figures are in China cases. In Pakistan 272 cases are confirmed by official and two deaths are occurred to date (18 March 2020).

\section{FATALITY RATIO}

A cohort research is conducted on 41 patients out of which half of the patients developed shortness of breath which immediately required intensive care and need to admit there. Notwithstanding, its fertility rate is not so much and it is about almost $14.6 \%$ and overall rate is fallen down about 4 percent. ${ }^{6}$ These two values required special treatment and precautionary measures because of weird disease patterns in relation with sign and symptoms. ${ }^{8}$ Although, case-fertility ration is overestimated at initial stages owing to severe case diagnosing scenarios. But possibilities of present case-fatality are gradually decreased. Nonetheless, 1918 contagion influenza attack had less than 5 percent case-fatality but with enormous side effects due to loss of social distancing among people. Hence, there is an issue which needs far-sighted approach rather than narrow approach. ${ }^{8}$

\section{HEALTH MEASURES}

Contemporary challenge, Corona Virus Covid-19 eruption has led to strategic implementation of procedures which would play an important in order to eradicate this menace. It would help to reduce its further spread from China to all over the world. In this tough situation, world health organization has not banned international travelling yet (till March 18, 2020), ${ }^{9}$ public transportation blocked down, airways restrictions, closure of railway stations and highway are important steps in order to eliminate further transmission of Dracula disease. For this, active investigations ways for incidence of severe disease and rigid monitoring system of close social contacts also being instigated. In order to combat this disease, mobile hospitals and staff with pro-active approach should established everywhere in the world. So, healthcare measures with latest technology equipped teams are required to remove this pandemic.

\section{PREVENTION}

Prevention is the only way to defeat this war like situation by disseminating information in every hook and nook of the world. In this regard, social media of every county would play an important role being a fourth pillar of a state. It must be top priority to disclosure of information related to control and prevention of corona virus. Education of the common man with simple ways is the ray of hope in whole darkness. For this, education campaigns are launched to promote precautionary measures including washing hands frequently, teach manners how to cough 
during public dealings, travelling care, use of mask with proper handling, and teach hygiene practices. Above mentioned are taught to public by practicing individually. It should be individual effort. The thing which is more important is to report sign and symptoms like fever, cough and sore throat when experienced. Travel history and close social contacts to suspected areas are also important factors which should not be ignored. New Jersey, USA corona spread is due to above two factors. Quarantine is started in Pakistan as well as other countries like Italy. Novel coronavirus pneumonia can be treated by chloroquine phosphate. It recommended chloroquine phosphate tablet $500 \mathrm{mg}$ twice daily for 10 days for patients diagnosed as novel coronavirus pneumonia without any contraindications. ${ }^{10}$

\section{WORLD ECONOMY}

According to latest research of World health organization, this dangerous disease has eaten more than 208,000 people in around 171 countries and become great havoc for them..$^{2,9}$ It is one of the biggest non-traditional security threats of the world which fallen down the global financial market. On the whole, it is the main cause of fragile economy doldrums of the world. Meritorious contributions of world's largest organizations such as Organization for Economic Co-operation and Development (OECD) have been seen fighting against Corona Virus.

\section{CHALLENGES}

It is an encounter and challenge of danger which must need special measures rather than careless behavior. Lesson must be learnt from those countries that did not bother this threat and faced miseries and helplessness. So it is a time to act with individual and collective efforts at all levels on whole globe without any boarder, religion and ethnicity discrimination.

\section{DISCUSSION}

China is a land of emerging economy where many of the contagious infections confirmed cases are round about one million have been reported till now (March 18, 2020). ${ }^{11}$ Covid-19, a global grave concern, epidemic occurrence in china at present destroyed activities of daily life of human beings.
Chinese government restricted mobility of public and sealed whole cities. Business of second super power destructed badly by suspension of all mandatory operations. Eventually, it slows down the rising world's second large economy of china. Things gone more worsen when this pandemic virus is spreading from Europe to middle East and made strong its tentacles everywhere in the world. It is not only increasing mortality rate in developing countries like Iran, India and Pakistan but also in developed countries such as France, Germany and Spain where more than 10,000 cases are reported right now (March 18, 2020). As the disease is spreading rapidly in other countries like Italy, Iran and South Korea reporting more than 30000,17000 and 8,000 respectively cases each to date (March 18, 2020), causing more hostile environment. This grave disease has more potential to increase in regions where cool weather is more prevalent. Its spreading rate is more than other virus because of its high therapeutic values. It directly hit the economy of the world from front line. ${ }^{11}$

\section{CONCLUSION}

The Covid-19 epidemic has spread very quickly. It took only 3-4 months to expand from China to the rest of the world. It is a serious illness if taken disproportionately it could panic and a threat of world economy to weaken it.

\section{Copyright $\odot 28$ Mar,2020}

\section{REFERENCES}

1. Wang C, Horby PW, Hayden FG, Gao GF. A novel coronavirus outbreak of global health concern. The Lancet. 2020 Feb 15; 395(10223):470-473.

2. Novel Coronavirus (2019-nCoV) situation reports - World Health Organization (WHO) https://www. worldometers.info/coronavirus/usa-coronavirus/.

3. Coronavirus: Iran reports leap in death toll. https:// www.bbc.com/news/world-middle-east-51801968.

4. Saudi locks down Qatif as coronavirus surges in the Gulf. https://www.aljazeera.com/news/2020/03/saudilocks-qatif-coronavirus-surges-gulf-200308142809697. html. 
5. Pakistan Links Some of Its 21 Coronavirus Cases to Syria. Coronavirus Outbreak; https://www.voanews. com/science-health/coronavirus-outbreak/pakistanlinks-some-its-21-coronavirus-cases-syria.

6. Chan JF, Yuan S, Kok KH, To KK, Chu H, Yang J, Xing F, Liu J, Yip CC, Poon RW, Tsoi HW. A familial cluster of pneumonia associated with the 2019 novel coronavirus indicating person-to-person transmission: a study of a family cluster. The Lancet. 2020 Feb 15; 395(10223):514-23.

7. Huang C, Wang Y, Li X, Ren L, Zhao J, Hu Y, Zhang L, Fan $\mathrm{G}, \mathrm{Xu}$ J, Gu X, Cheng Z. Clinical features of patients infected with 2019 novel coronavirus in Wuhan, China. The Lancet. 2020 Feb 15; 395(10223):497-506.

8. Leung GM, Hedley AJ, Ho LM, Chau P, Wong IO, Thach TQ, Ghani AC, Donnelly CA, Fraser C, Riley S, Ferguson NM. The epidemiology of severe acute respiratory syndrome in the 2003 Hong Kong epidemic: An analysis of all 1755 patients. Annals of internal medicine. 2004 Nov 2; 141(9):662-73.
9. World Health Organization. Novel Coronavirus (2019nCoV) Situation report-5, 25 January 2020. Geneva, Switzerland. 2020.

10. Cortegiani A, Ingoglia G, Ippolito M, Giarratano A, Einav $S$. A systematic review on the efficacy and safety of chloroquine for the treatment of COVID-19. Journal of Critical Care. 2020 Mar 10.

11. Lee, YN. 6 charts show the coronavirus impact on the global economy and markets so far. World economy. March 2020. https://www.cnbc.com/2020/03/12/ coronavirus-impact-on-global-economy-financialmarkets-in-6-charts.html.

\begin{tabular}{|c|c|c|}
\hline \multicolumn{3}{|c}{ AUTHORSHIP AND CONTRIBUTION DECLARATION } \\
\hline Sr. \# & \multicolumn{1}{|c|}{ Author(s) Full Name } & \multicolumn{1}{c}{ Contribution to the paper } \\
\hline 1 & Naveed Arshad & $\begin{array}{l}\text { Conception, Design, Synthesis } \\
\text { and search the data, Revision } \\
\text { of the disease, drafting of } \\
\text { article. } \\
\text { Active participation in } \\
\text { discussion. } \\
\text { Critical revision of the } \\
\text { manuscript. }\end{array}$ \\
\hline 3 & Syed Ali Naqi & Jais Karmani \\
\hline
\end{tabular}

